\title{
THE REGENERATION OF SULPHATED STORAGE CELLS
}

\author{
BY G. A. PERLEY AND C. W. DAVIS
}

In the preceding paper ${ }^{1}$ it was shown that the formation of lead crystals, when a sulphated lead strip is dipped into caustic soda solution, is due to the action of myriads of concentration cells. From these experiments it follows that it should be possible to regenerate a sulphated storage cell after a fashion by standing it in a caustic soda solution without using any external source of current. This can be done but the method is not satisfactory, because the lead is not precipitated in a suitable form and because the caustic soda solution dissolves a large amount of lead sulphate, which is a complete loss.

Some years ago, one of the authors ${ }^{2}$ showed that sulphated storage cells could be regenerated satisfactorily if the battery acid were replaced by a solution of sodium sulphate. Upon the passage of a normal charging current, the lead sulphate is reduced within sixty hours even on badly sulphated grids. This method has since been tried by various people, always with good results. One great advantage of the method was that no new acid radical was introduced into the cell and that there was no need of a laborious and possibly ineffective washing before putting the cell in commission. On the other hand, it was conceivable that some other salt might give deposits that were enough better to justify its use, and accordingly some experiments have been. made with other sodium salts. The comparative data are given in Table I. In all of these experiments $4^{\prime \prime} \times 5^{\prime \prime}$ badly sulphated storage battery grids were used. The current density was 6.5 amperes per square foot. Normal solutions of all of the electrolytes were taken. All the solutions except those of

1 Perley and Davis: Jour. Phys. Chem., 20, I5 I (1916).

2Perley: Jour. Phys. Chem., 15, 489 (1911); Bennett and Cole: Trans. Am. Electrochem. Soc, 2I, 303 (I9I2). 
the salts plus alkali were clear at the start. At the end of the run the sulphite solution was turbid and brown while the solutions containing caustic soda were turbid and yellow; all the others were clear.

TABLE I

\begin{tabular}{|c|c|c|c|c|}
\hline \multirow{2}{*}{ Solutions } & \multicolumn{2}{|c|}{ Aciclity } & \multicolumn{2}{|c|}{ After 2 hours } \\
\hline & Start & Iind & Cathode & Anode \\
\hline $\mathrm{NaOH}$ & Alkaline & Alkaline & $\begin{array}{l}\text { Jellow } \\
\text { coating }\end{array}$ & $\begin{array}{l}\text { Brown } \\
\mathrm{PbO}\end{array}$ \\
\hline $\mathrm{Xa}_{2} \mathrm{SO}_{3}$ & Neutral & Acid & $\begin{array}{l}\text { Partly } \\
\text { reduced }\end{array}$ & $\begin{array}{l}\text { Brown } \\
\mathrm{PbO}_{2}\end{array}$ \\
\hline $\mathrm{Na}_{2} \mathrm{SO}_{3}$ & Alkaline & Acid & $\begin{array}{l}\text { Brittle } \\
\text { lead } \\
\text { buckling }\end{array}$ & $\begin{array}{l}\text { Gray } \\
\text { brown } \\
\mathrm{PbO}^{2}\end{array}$ \\
\hline $\mathrm{Na}_{2} \mathrm{CO}_{3}$ & Alkaline & Alkaline & $\begin{array}{l}\text { White } \\
\text { reduced } \\
\text { at edges }\end{array}$ & $\begin{array}{l}\text { Brown } \\
\mathrm{PbO}_{2}\end{array}$ \\
\hline $\mathrm{Na}_{2} \mathrm{HPO}_{4}$ & Alkaline & Neutral & $\begin{array}{l}\text { Partly } \\
\text { reduced }\end{array}$ & $\begin{array}{l}\text { Gray } \\
\text { coating }\end{array}$ \\
\hline $\mathrm{NaClO}_{3}$ & Acid & Acid & $\begin{array}{l}\text { Spongy } \\
\text { lead }\end{array}$ & $\begin{array}{l}\text { No } \\
\text { change }\end{array}$ \\
\hline $\mathrm{Na}$ acetate & $\begin{array}{l}\text { Slightly } \\
\text { alkaline }\end{array}$ & Neutral & $\begin{array}{l}\text { Mass of } \\
\text { crystals }\end{array}$ & $\begin{array}{l}\text { Gray } \\
\text { yellow }\end{array}$ \\
\hline Na oxalate & Acid & Acid & $\begin{array}{l}\text { Básic } \\
\text { salts }\end{array}$ & $\begin{array}{l}\text { Basic } \\
\text { salts }\end{array}$ \\
\hline Na tartrate & Acid & Acid & $\begin{array}{l}\text { Basic } \\
\text { salts }\end{array}$ & $\begin{array}{l}\text { Basic } \\
\text { salts }\end{array}$ \\
\hline $\begin{array}{l}\text { Above salts } \\
\text { plus } \mathrm{NaOH}\end{array}$ & Alkaline & Alkaline & $\begin{array}{l}\text { Yellow } \\
\text { coating }\end{array}$ & $\begin{array}{l}\text { Brown } \\
\mathrm{PbO}_{2}\end{array}$ \\
\hline
\end{tabular}

From the experiments it appears that a sulphated grid may be reduced in whole or in part with solutions of sodium sulphate, sodium carbonate, sodium phosphate or sodium sulphite. The rate of reduction is the fastest and the cathode and anode corrosion the least in the sulphate solution. The only solutions which give a good deposit of lead peroxide from sulphated anodes are the sulphate, carbonate, and hydroxide. The phosphate is converted slowly to lead peroxide at the anode. Insoluble salts (chiefly lead hydroxide) form as a sludge in the case of the hydroxide, acetate, and tartrate solutions. 
When using the sodium sulphate method, we found that far better reduction occurred if two outer dummy positive grids were employed in addition to the usual number of positives. If not, the two outer negative surfaces require a much longer time for regeneration. This alone saves much time in the reduction. There is no question but that a badly sulphated grid may be brought to a high state of efficiency if sufficient time be allowed, approximately sixty hours at the normal charging rate. The chief objection-and possibly not an over serious one-is the fact that the concentration of acid increases with the duration of the run, and this tends to neutralize the alkali formed at the cathode. It is possible to prevent the diffusion of acid by wooden partitions, or to neutralize the acid from time to time, yet both of these methods are awkward.

Off-hand it seemed as though a very dilute solution of sodium hydroxide might prove a fairly efficient electrolyte. In all of the experiments, however, in which sodium hydroxide was used as the electrolyte, either alone or combined with other salts, a yellow precipitate of lead oxide was formed after the current had been flowing for about an hour. This precipitate clouded the solution and caused no end of trouble by settling on the electrodes and containers. This is due to the corrosion of the lead anode, sodium plumbite being formed which afterwards hydrolyzes. With sodium sulphate as electrolyte there is no excess of alkali at the anode and consequently no appreciable formation of plumbite.

Lead carbonate is much less soluble in sodium carbonate and hydroxide than lead sulphate is in sodium sulphate and hydroxide. Consequently when sodium carbonate is used as electrolyte, the sulphate is converted at the cathode into an insoluble basic carbonate which is reduced much more slowly than is lead sulphate. The regeneration therefore takes place at a very slow rate. A very fine anode deposit of lead peroxide is always obtained from a sulphated grid in a carbonate solution.

The rate of reduction of lead sulphate is quite rapid in a 
sodium phosphate solution; but there is a perceptible anode corrosion, so that active material is removed from the grid. There is apparently a tendency also to form a basic salt of some sort at the anode, as evidenced by the formation of a gray coating in a few spots where lead sulphate had existed. The chief difficulties with this solution are the high anode corrosion and the slowness with which the lead sulphate is converted at the anode to lead peroxide. The lead which results at the cathode from the reduction in a sulphite solution differs decidedly from that obtained in all of the other solutions. A very hard crystalline metal is deposited which causes more or less severe buckling of the grids. In the acetate, oxalate, and tartrate solutions the sparing solubility of the basic lead salts formed in presence of alkali causes so much trouble through crystallization of the salts on the electrodes that these solutions are valueless.

The experiments point to the following general conclusions:

I. Sodium sulphate is the best salt to use in regenerating positive and negative storage battery grids.

2. Dummy positive grids on the outside of the negative plates cut down the time of reduction.

3. Hydrolysis of the lead salts formed in sodium hydroxide solution yields large and troublesome quantities of lead monoxide. The active material of the grids is removed to a considerable extent.

4. With sodium sulphite solutions a hard crystalline lead is deposited at the cathode which causes buckling of the grids.

5. Reduction in whole or in part of a sulphated grid results by the use of a solution of sodium sulphate, carbonate, phosphate, or sulphite.

6. Good anode deposits from sulphated grids can be obtained only with sulphate, carbonate, and hydroxide solutions. This relatively high anode corrosion with sodium hydroxide solutions makes these useless.

New Hampshire College

Durham, N. H. 